\title{
Sequence diversity and differential expression of major phenylpropanoid- flavonoid biosynthetic genes among three mango varieties
}

Van L. T. Hoang ${ }^{1,2}$, David J. Innes ${ }^{3}$, P. Nicholas Shaw ${ }^{1,2}$, Gregory R. Monteith', Michael J. Gidley ${ }^{2}$ and Ralf G. Dietzgen ${ }^{1,2^{*}}$

\begin{abstract}
Background: Mango fruits contain a broad spectrum of phenolic compounds which impart potential health benefits; their biosynthesis is catalysed by enzymes in the phenylpropanoid-flavonoid (PF) pathway. The aim of this study was to reveal the variability in genes involved in the PF pathway in three different mango varieties Mangifera indica L., a member of the family Anacardiaceae: Kensington Pride (KP), Irwin (IW) and Nam Doc Mai (NDM) and to determine associations with gene expression and mango flavonoid profiles.

Results: A close evolutionary relationship between mango genes and those from the woody species poplar of the Salicaceae family (Populus trichocarpa) and grape of the Vitaceae family (Vitis vinifera), was revealed through phylogenetic analysis of PF pathway genes. We discovered 145 SNPs in total within coding sequences with an average frequency of one SNP every $316 \mathrm{bp}$. Variety IW had the highest SNP frequency (one SNP every 258 bp) while KP and NDM had similar frequencies (one SNP every $369 \mathrm{bp}$ and $360 \mathrm{bp}$, respectively). The position in the PF pathway appeared to influence the extent of genetic diversity of the encoded enzymes. The entry point enzymes phenylalanine lyase (PAL), cinnamate 4-mono-oxygenase (C4H) and chalcone synthase (CHS) had low levels of SNP diversity in their coding sequences, whereas anthocyanidin reductase (ANR) showed the highest SNP frequency followed by flavonoid $3^{\prime}$-hydroxylase $\left(F 3^{\prime} H\right)$. Quantitative PCR revealed characteristic patterns of gene expression that differed between mango peel and flesh, and between varieties.

(Continued on next page)
\end{abstract}

\footnotetext{
* Correspondence: r.dietzgen@uq.edu.au

'School of Pharmacy, The University of Queensland, Brisbane, Queensland, Australia

${ }^{2}$ Centre for Nutrition and Food Sciences, Queensland Alliance for Agriculture and Food Innovation, The University of Queensland, Brisbane, Queensland,

Australia

Full list of author information is available at the end of the article
} 
(Continued from previous page)

Conclusions: The combination of mango expressed sequence tags and availability of well-established reference PF biosynthetic genes from other plant species allowed the identification of coding sequences of genes that may lead to the formation of important flavonoid compounds in mango fruits and facilitated characterisation of single nucleotide polymorphisms between varieties. We discovered an association between the extent of sequence variation and position in the pathway for up-stream genes. The high expression of $\mathrm{PAL}, \mathrm{C} 4 \mathrm{H}$ and $\mathrm{CHS}$ genes in mango peel compared to flesh is associated with high amounts of total phenolic contents in peels, which suggest that these genes have an influence on total flavonoid levels in mango fruit peel and flesh. In addition, the particularly high expression levels of ANR in KP and NDM peels compared to IW peel and the significant accumulation of its product epicatechin gallate (ECG) in those extracts reflects the rate-limiting role of ANR on ECG biosynthesis in mango.

Keywords: Mango fruit, Expressed sequence tags, Phenylpropanoid-flavonoid pathway, Nucleotide diversity, Gene expression

\section{Background}

The PF pathway in fruits and vegetables is of great interest because it leads to compounds that exhibit important health benefits, including antioxidant, antibacterial, anti-inflammatory and anticarcinogenic effects [1]. This pathway is highly conserved among diverse plant species and is well defined in Arabidopsis thaliana (Family: Brassicaceae) and several temperate fruit species including grape, apple, berry and olive fruits [2-8]. Mango is the fifth largest fruit crop in the world [9] and a good candidate for research on phytochemical improvement to create better fruit value, because of its high genetic diversity [10] and the current lack of breeding for nutritional quality. Mango fruits are rich sources of phytochemicals, including antioxidants and other potential health-promoting compounds [11]. A comparative bioactivity study between the three genetically diverse mango varieties KP, IW and NDM showed differential effects on lipid accumulation in 3 T3-L1 pre-adipocyte mouse embryo fibroblasts [12]. A parallel study of mango chemical profiles in the same extracts has shown a clear difference in major phenolic components between these varieties [13]. The total phenolic content of Kensington Pride, Irwin and Nam Doc Mai peel and flesh extracts has been recently reported with Nam Doc Mai peel extract containing the highest amount of polyphenolics [12].

Mango fruit studies have previously largely focused on the ripening process [14-16], volatile composition $[17,18]$, postharvest treatment and fruit quality [19] at the physiological level. Earlier studies have isolated 18 genes associated with the physiology and biochemistry of mango fruits and their gene expression was profiled during fruit development [20]; no detailed sequence information was reported. Recently, the first mango genome and transcriptome data were reported [21-23]. More than 13,500 unigenes of mango were assigned to 293 KEGG pathways [22] however genes were limited to the chloroplast genome and expression in leaf tissues. In another study, transcriptome sequencing of a mixed fruit sample containing flesh and peel of mango variety Zill during fruit ripening was reported [21]. These authors assembled 54,000 transcripts and matched mango transcripts to 2754 proteins [20], but did not correlate expressed mango genes and mango phytochemicals. A mango fruit peel transcriptome in response to hot water treatment, which included flavonoid genes has also been reported [23].

The level of nucleotide sequence variation, the position of the gene products in the pathway and the expression levels of genes all contribute to the abundance and chemical diversity of bioactive compounds [24]. The most frequent type of sequence variations are single nucleotide differences, which are generally referred to as single nucleotide polymorphisms (SNPs) [25]. SNPs within a coding sequence may change amino acid sequence and therefore potentially affect protein function [26, 27]. Sequence diversity of enzymes in the phenylpropanoid-flavonoid (PF) pathway has been studied in detail in the model species Arabidopsis thaliana $[6,28]$ and in important field crops such as maize (Zea mays) (Family: Poaceae) [29] and barley (Hordeum vulgare) (Family: Poaceae) [30].

In this paper, we report the sequence variability of genes involved in the PF biosynthesis of mangoes of different genetic origin and the relative levels of gene expression in order to assess the potential role of these genes in governing accumulation of flavonoid compounds in mango fruits. Our study was aimed at investigating health benefits of consuming mango fruit; for this reason, we studied the expression of mango genes and associated bioactive polyphenolic compounds at the mature ripe fruit stage. Previously, the Mango Genomics Initiative of the Queensland Department of Agriculture and Fisheries generated 25,000 expressed sequence tags (ESTs) from cDNA libraries of KP root, leaf, flower and fruit tissues as well as from IW leaf tissue [31] which 


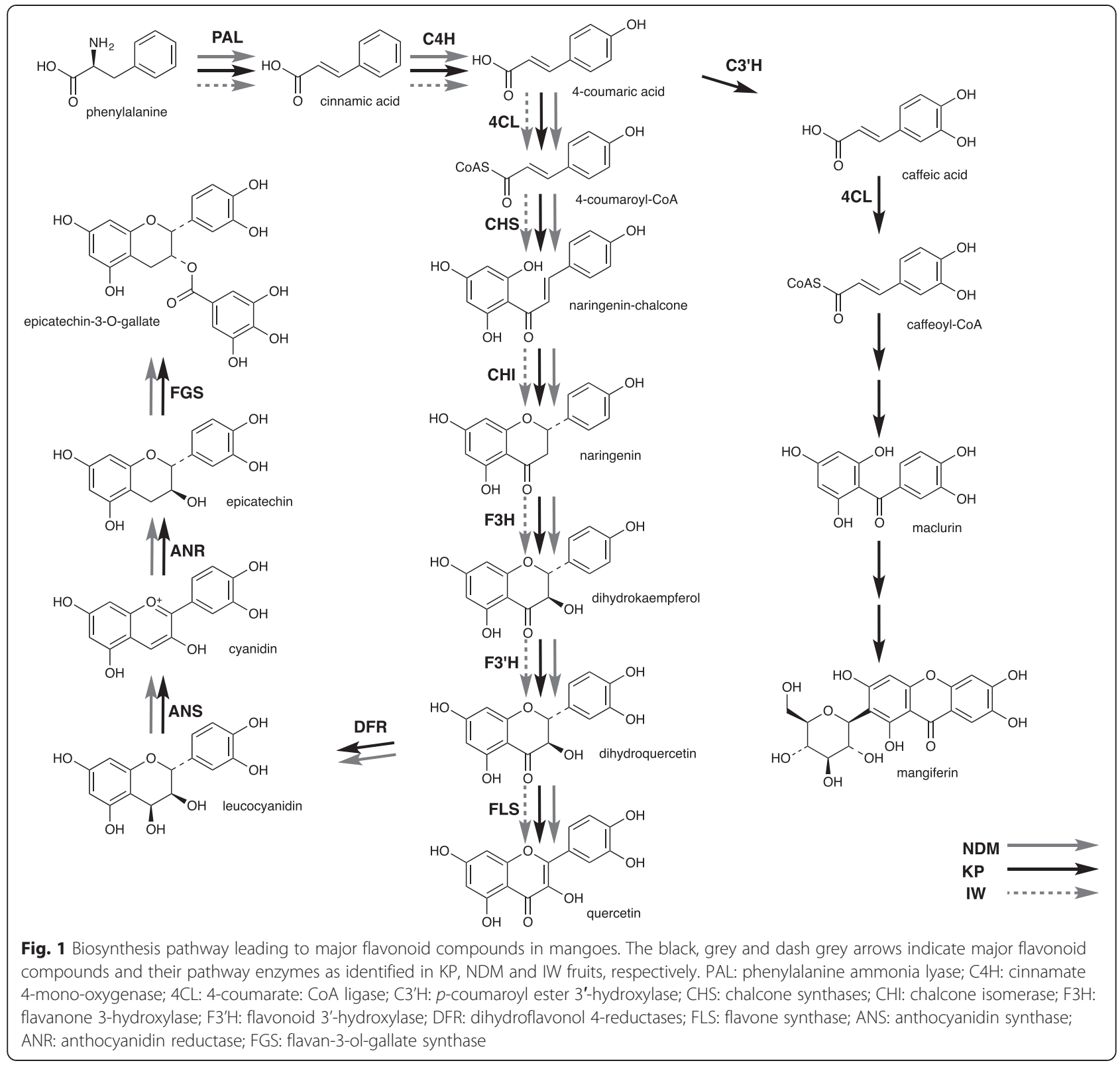

enabled this comparative study. Based on a combination of results from automated data extraction from the Kyoto Encyclopedia of Genes and Genomes (KEGG; www.genome.jp/kegg/) and the presence of selected flavonoids in our mango extracts [13], we also propose here a mango fruit PF pathway, with particular emphasis on the mango signature compounds mangiferin and epicatechin-3-O-gallate [32, 33] (Fig. 1).

\section{Results and discussion}

Identification of PF pathway candidate genes from a mango EST library

To identify PF biosynthesis genes, we performed an in silico screen of the mango EST database sequences. A total of 12 candidate genes for PAL, $\mathrm{C} 4 \mathrm{H}, p$-coumaroyl ester 3'-hydroxylase $\left(\mathrm{C}^{\prime} \mathrm{H}\right)$, 4-coumarate:CoA ligase (4CL), CHS1, CHS2, flavanone 3-hydroxylase (F3H1, F3H2), F3'H, dihydroflavonol 4-reductases (DFR), anthocyanidin synthase (ANS) and ANR with annotations matching enzymes in the PF pathway leading to ECG and mangiferin biosynthesis were identified. This information was used to design PCR strategies for the amplification of the coding regions of these genes using cDNA prepared from KP, IW and NDM fruit. All individual sequences have been deposited in GenBank (Table 1).

Phylogenetic comparisons of the translated consensus sequences of mango PF pathway proteins against corresponding sequences of a selected plant reference protein 
Table 1 List of Genbank accession numbers of mango genes

\begin{tabular}{|c|c|c|}
\hline Gene & Mango variety & Accession numbers \\
\hline \multirow[t]{3}{*}{$\overline{P A L}$} & $\mathrm{KP}$ & KF956008 \\
\hline & IW & KF956009 \\
\hline & NDM & KF956010 \\
\hline \multirow[t]{3}{*}{$\mathrm{C} 4 \mathrm{H}$} & KP & KF956011 \\
\hline & IW & KF956012 \\
\hline & NDM & KF956013 \\
\hline \multirow[t]{3}{*}{$4 C L$} & $\mathrm{KP}$ & KF956014 \\
\hline & IW & KF956015 \\
\hline & NDM & KF956016 \\
\hline \multirow[t]{3}{*}{$\mathrm{C}^{\prime} \mathrm{H}$} & $\mathrm{KP}$ & KF956017 \\
\hline & IW & KF956018 \\
\hline & NDM & KF956019 \\
\hline \multirow[t]{3}{*}{ CHS1 } & $\mathrm{KP}$ & KF956020 \\
\hline & IW & KF956021 \\
\hline & NDM & KF956022 \\
\hline \multirow[t]{3}{*}{ CHS2 } & $\mathrm{KP}$ & KF956023 \\
\hline & IW & KF956024 \\
\hline & NDM & KF956025 \\
\hline \multirow[t]{3}{*}{$\mathrm{F} 3 \mathrm{H} 1$} & $\mathrm{KP}$ & KF956026 \\
\hline & IW & KF956027 \\
\hline & NDM & KF956028 \\
\hline \multirow[t]{3}{*}{$\mathrm{F} 3 \mathrm{H} 2$} & $\mathrm{KP}$ & KF956029 \\
\hline & IW & KF956030 \\
\hline & NDM & KF956031 \\
\hline \multirow[t]{3}{*}{$\mathrm{F} 3^{\prime} \mathrm{H}$} & $\mathrm{KP}$ & KF956032 \\
\hline & IW & KF956033 \\
\hline & NDM & KF956034 \\
\hline \multirow[t]{3}{*}{ DFR } & $\mathrm{KP}$ & KF956035 \\
\hline & IW & KF956036 \\
\hline & NDM & KF956037 \\
\hline \multirow[t]{3}{*}{ ANS } & $\mathrm{KP}$ & KF956038 \\
\hline & IW & KF956039 \\
\hline & NDM & KF956040 \\
\hline \multirow[t]{3}{*}{ ANR } & $\mathrm{KP}$ & KF956041 \\
\hline & IW & KF956042 \\
\hline & NDM & KF956043 \\
\hline
\end{tabular}

set, available through GenBank, revealed that the two closest neighbours of mango were $P$. trichocarpa and $V$. vinifera (Fig. 2; data not shown). Similar results were reported recently based on the evolutionary relationship between actins from those plant species [34] and on mango chloroplast genes which showed a close relationship between mango, $P$. trichocarpa, $V$. vinifera and Citrus sinensis (Family: Rutaceae) as closest neighbour [22].

\section{SNPs analysis}

Multiple sequence alignments showed that the PF pathway genes of the three mango varieties tested have similar lengths, and high sequence identity with a range of 95.7-99.9\%, implying conservation of each gene sequence between varieties. There were no deletions or insertions in any of the amplified gene fragments and no mutations that introduced premature stop codon that would generate a truncated protein. However, there was variation in sequences between the three mango varieties studied. Overall, we detected 145 polymorphic sites across the entire $46,560 \mathrm{bp}$ of nucleotide sequence of the 12 PF biosynthetic genes analysed. Of these, 84 were synonymous SNPs or silent changes and 61 were nonsynonymous SNPs, which would lead to changes in the encoded amino acid. The IW variety had approximately $30 \%$ more SNPs than the other two varieties although IW and KP had the same number of non-synonymous SNPs. The overall frequency of SNPs in the three mango varieties tested was one in every $316 \mathrm{bp}$. Variety IW had the highest SNP frequency (one SNP every $258 \mathrm{bp}$ ) while KP and NDM had similar frequencies (one SNP every $369 \mathrm{bp}$ and $360 \mathrm{bp}$, respectively). This SNP frequency is close to that reported in coding regions in black cottonwood (P. trichocarpa) (one SNP per $229 \mathrm{bp)} \mathrm{[35],} \mathrm{higher}$ than in soybean (Glycine max) (Family: Fabaceae) (one SNP every 504 - 609 bp) [36] but lower than highly polymorphic plant species such as maize (Zea mays) or grape (V. vinifera) (approximately one SNP every 69 bp) [37, 38].

Table 2 summarises the sequenced length of each gene fragment, the number of SNPs, the number of nonsynonymous SNPs and the number of SNPs per $1000 \mathrm{bp}$ of individual genes in each mango variety. Overall, levels of polymorphism varied across genes within varieties and between varieties; and variation was lower at nonsynonymous sites than at synonymous sites between varieties. Genes of the variety IW had the highest levels of SNP diversity, especially in the 4CL gene (11.6 SNPs in $1000 \mathrm{bp}$ ). This variety has a different phytochemical content compared to KP and NDM [13]. The gene with the lowest number of SNPs per 1000 bp was F3H1 (0.8 SNPs in $1000 \mathrm{bp}$ ) while the gene with the highest SNP frequency was ANR (8.8 SNPs in $1000 \mathrm{bp}$ ), followed by F3'H (Table 2). The nucleotide and non-synonymous variation was found to be low in PAL, C4H and $\mathrm{CHS}$ genes (Table 2). These three genes are located at the entry to the PF biosynthetic pathway. A previous study by Lu and Rausher [39] that analysed anthocyanin pathways in monocot and dicot species also showed that downstream genes exhibited significantly greater divergence rates than upstream genes. Similar patterns of variation were found in genes of the carotenoid biosynthetic pathway for tomato, carrot and rice [40]. This can be explained because upstream enzymes provide 

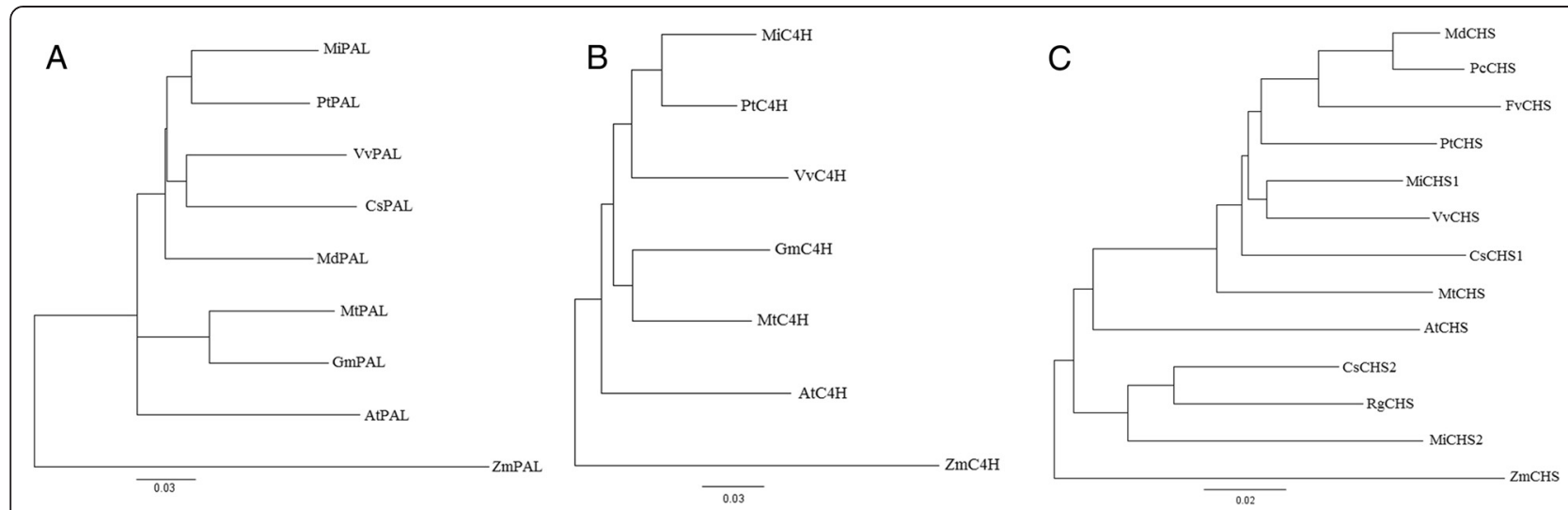

Fig. 2 Neighbour-joining trees of selected plant PAL (a), C4H (b) and CHS (c) proteins. Bootstrap values above $50 \%$ are indicated at nodes. The tree is drawn to scale, with branch lengths in the same units as those of the evolutionary distances that were used to infer the phylogenetic tree. PtPAL (Populus trichocarpa GenBank: XP_002315308), VvPAL (Vitis vinifera GenBank: XP_002272926), CsPAL (Citrus sinensis GenBank: XP_006488063), MdPAL (Malus domestica, Family: Rosaceae, GenBank: AFG30054), MtPAL (Medicago truncatula, Family: Fabaceae, GenBank:P_003590471), GmPAL (Glycine max GenBank: NP_001236956), AtPAL (Arabidopsis thaliana GenBank:NP_187645), ZmPAL (Zea mays GenBank: NP_001105334), PtC4H (Populus trichocarpa GenBank:XP_002319974), VvC4H (Vitis vinifera GenBank: XP_002266238), MtC4H (Medicago truncatula GenBank: XP_003616037), GmC4H (Glycine max GenBank: NP_001237317), AtC4H (Arabidopsis thaliana GenBank: NP_180607), ZmC4H (Zea mays GenBank: NP_001149158), MdCHS (Malus domestica GenBank: ACJ54531), FvCHS (Fragaria vesca, Family: Rosaceae, GenBank: XP_004306542), PcCHS (Pyrus communis, Family: Rosaceae, GenBank: AAX16494), PtCHS (Populus trichocarpa GenBank: XP_002303821), VvCHS (Vitis vinifera GenBank: AEP17003), CsCHS1 (Citrus sinensis GenBank: Q9XJ57), CsCHS2 (Citrus sinensis GenBank: Q9XJ58), MtCHS (Medicago truncatula GenBank: XP_003601647), AtCHS (Arabidopsis thaliana GenBank: P13114), RgCHS (Ruta graveolens, Family: Rutaceae, GenBank:Q9FSB9), ZmCHS (Zea mays GenBank:NP_001149022)

precursors for various groups of end-products and control the flux into the pathways. Changes in their coding regions could have major effects on plant phytochemical biosynthesis and therefore could greatly affect the accumulation of various end products.

The sequence positions of identified mutations and the alleles present in the three mango varieties are presented in Table 3. Most SNPs occurred outside of the reported conserved regions thought to be important for enzyme function. There has been no previous report about the effects of SNPs at these positions in other plant species. However, even SNPs that do not change the amino acid sequence or SNPs that do not alter protein activity, can still be useful as genetic markers [41]. Additionally, most of the genes showed the presence of one or two allelic sequences, which confirms the heterozygosity of the KP, IW and NDM genomes [31].

Table 2 Summary of alignment length, number of SNPS, number of non-synonymous SNPs and the frequency of SNPs per 1,000 bp of 12 genes of the phenylpropanoid-flavonoid pathways in each of three mango varieties

\begin{tabular}{|c|c|c|c|c|c|c|c|c|c|c|c|}
\hline \multirow[t]{2}{*}{ Gene } & \multirow{2}{*}{$\begin{array}{l}\text { Length } \\
\text { (bp) }\end{array}$} & \multicolumn{3}{|l|}{$\mathrm{KP}$} & \multicolumn{3}{|l|}{ IW } & \multicolumn{3}{|l|}{ NDM } & \multirow{2}{*}{$\begin{array}{l}\text { SNPs } \\
\text { per } \\
1,000 \mathrm{bp}\end{array}$} \\
\hline & & $\begin{array}{l}\text { No. of } \\
\text { SNPS }\end{array}$ & $\begin{array}{l}\text { No. of non- } \\
\text { synonymous }\end{array}$ & $\begin{array}{l}\text { SNPs per } \\
1,000 \text { bp }\end{array}$ & $\begin{array}{l}\text { No. of } \\
\text { SNPs }\end{array}$ & $\begin{array}{l}\text { No. of non- } \\
\text { synonymous }\end{array}$ & $\begin{array}{l}\text { SNPs per } \\
1,000 \mathrm{bp}\end{array}$ & $\begin{array}{l}\text { No. of } \\
\text { SNPs }\end{array}$ & $\begin{array}{l}\text { No. of non- } \\
\text { synonymous }\end{array}$ & $\begin{array}{l}\text { SNPs per } \\
1,000 \text { bp }\end{array}$ & \\
\hline $\mathrm{PAL}$ & 2,123 & 2 & 1 & 0.9 & 5 & 3 & 2.4 & 4 & 1 & 1.9 & 1.9 \\
\hline $\mathrm{C} 4 \mathrm{H}$ & 1,499 & 0 & 0 & - & 0 & 0 & - & 6 & 5 & 4 & 1.3 \\
\hline $4 C L$ & 1,637 & 1 & 1 & 0.6 & 19 & 9 & 11.6 & 0 & 0 & - & 4.1 \\
\hline$C 3^{\prime} \mathrm{H}$ & 1,524 & 8 & 1 & 5.2 & 6 & 0 & 3.9 & 5 & 1 & 3.3 & 4.2 \\
\hline CHS1 & 1,171 & 3 & 2 & 2.5 & 6 & 0 & 5.1 & 1 & 0 & 0.9 & 2.8 \\
\hline CHS2 & 1,179 & 0 & 0 & - & 1 & 0 & 0.8 & 2 & 0 & 1.7 & 0.8 \\
\hline $\mathrm{F} 3 \mathrm{H} 1$ & 1,082 & 0 & 0 & - & 1 & 1 & 0.9 & 0 & 0 & - & 0.3 \\
\hline $\mathrm{F} 3 \mathrm{H} 2$ & 1,075 & 10 & 6 & 9.3 & 6 & 4 & 5.6 & 2 & 0 & 1.9 & 5.6 \\
\hline F3'H & 1,548 & 9 & 5 & 5.8 & 7 & 2 & 4.5 & 12 & 6 & 7.7 & 6.0 \\
\hline DFR & 1,002 & 1 & 1 & 1 & 0 & 0 & 0 & 1 & 0 & 1 & 0.7 \\
\hline ANS & 919 & 1 & 0 & 1.1 & 4 & 2 & 4.4 & 1 & 0 & 1.1 & 2.2 \\
\hline ANR & 761 & 6 & 5 & 7.9 & 5 & 1 & 6.5 & 9 & 4 & 11.8 & 8.8 \\
\hline
\end{tabular}


Table 3 Characteristics of non-synonymous SNPs of 12 genes of the phenylpropanoid-flavonoid pathways in three mango varieties

\begin{tabular}{|c|c|c|c|c|c|c|}
\hline Gene & $\begin{array}{l}\text { SNP } \\
\text { position }\end{array}$ & Context & $\begin{array}{l}\text { Amino acid } \\
\text { replacement }\end{array}$ & $\mathrm{KP}$ & IW & NDM \\
\hline \multirow[t]{5}{*}{$\overline{P A L}$} & 399 & $(\mathrm{~A} / \mathrm{G}) \mathrm{TG}$ & Ser - Gly & A & G & A \\
\hline & 702 & $(\mathrm{~A} / \mathrm{G}) \mathrm{GT}$ & Ser - Gly & A & A & G \\
\hline & 718 & $\mathrm{G}(\mathrm{A} / \mathrm{T}) \mathrm{G}$ & Glu - Val & $\mathrm{A} / \mathrm{T}$ & A & A \\
\hline & 1,387 & $\mathrm{C}(\mathrm{T} / \mathrm{C}) \mathrm{T}$ & Leu - Pro & $\mathrm{T}$ & $\mathrm{T} / \mathrm{C}$ & $\mathrm{T}$ \\
\hline & 1,980 & $(\mathrm{G} / \mathrm{A}) \mathrm{CA}$ & Ala - Thr & G & A & G \\
\hline \multirow[t]{5}{*}{$\mathrm{C} 4 \mathrm{H}$} & 52 & $(G / A) T T$ & Val - Ile & G & G & $\mathrm{G} / \mathrm{A}$ \\
\hline & 124 & $(\mathrm{C} / \mathrm{G}) \mathrm{TT}$ & Leu - Val & $C$ & C & $C / G$ \\
\hline & 183 & $\Pi(\mathrm{A} / \mathrm{C})$ & Leu - Phe & A & A & $\mathrm{A} / \mathrm{C}$ \\
\hline & 205 & $(\mathrm{C} / \mathrm{T}) \Pi \mathrm{T}$ & Leu - Phe & $C$ & C & $C / T$ \\
\hline & 751 & $(\mathrm{C} / \mathrm{A}) \mathrm{AA}$ & Gln - Lys & C & C & $C / A$ \\
\hline \multirow[t]{8}{*}{$4 \mathrm{CL}$} & 56 & $\mathrm{C}(\mathrm{C} / \mathrm{T}) \mathrm{T}$ & Pro - Leu & $C / T$ & C & C \\
\hline & 206 & $\mathrm{G}(\mathrm{T} / \mathrm{C}) \mathrm{C}$ & Val - Ala & $\mathrm{T}$ & C & $\mathrm{T}$ \\
\hline & 247 & $(\mathrm{C} / \mathrm{A}) \mathrm{TG}$ & Leu - Met & C & A & C \\
\hline & 304,306 & $(\mathrm{C} / \mathrm{G}) \mathrm{G}(\mathrm{C} / \mathrm{T})$ & Arg - Gly & CGC & GTG & CGC \\
\hline & 433 & $(\mathrm{~A} / \mathrm{G}) \mathrm{AA}$ & Lys - Glu & A & G & A \\
\hline & 1,159 & $(\mathrm{C} / \mathrm{G}) \mathrm{CA}$ & Pro - Ala & C & G & C \\
\hline & 1,290 & $\mathrm{GA}(\mathrm{A} / \mathrm{T})$ & Glu - Asp & A & $\mathrm{T}$ & A \\
\hline & 1,557 & $\mathrm{GA}(\mathrm{T} / \mathrm{A})$ & Asp - Glu & $\mathrm{T}$ & A & $\mathrm{T}$ \\
\hline \multirow[t]{2}{*}{$C 3^{\prime} \mathrm{H}$} & 797 & $\mathrm{G}(\mathrm{T} / \mathrm{C}) \mathrm{C}$ & Val - Ala & $\mathrm{T}$ & $\mathrm{T}$ & $C$ \\
\hline & 803 & $\mathrm{CA}(\mathrm{A} / \mathrm{T})$ & $\mathrm{Gln}-\mathrm{His}$ & $\mathrm{T}$ & A & A \\
\hline \multirow[t]{2}{*}{ CHS1 } & 247 & $(G / A) T T$ & Val - Ile & A & G & G \\
\hline & 253 & $(\mathrm{G} / \mathrm{C}) \mathrm{AA}$ & Glu - Gln & C & G & G \\
\hline $\mathrm{F} 3 \mathrm{H} 1$ & 902 & $\mathrm{~T}(\mathrm{~A} / \mathrm{G}) \mathrm{C}$ & Tyr - Cys & A & G & A \\
\hline \multirow[t]{10}{*}{$\mathrm{F} 3 \mathrm{H} 2$} & 14 & $\mathrm{~A}(\mathrm{C} / \mathrm{G}) \mathrm{T}$ & Thr - Ser & C & G & C \\
\hline & 161 & $\mathrm{G}(\mathrm{G} / \mathrm{A}) \mathrm{T}$ & Gly - Asp & G & A & G \\
\hline & 271 & $(\mathrm{~A} / \mathrm{G}) \mathrm{AA}$ & Lys - Glu & G & A & A \\
\hline & 284 & $\mathrm{~T}(\mathrm{~T} / \mathrm{C}) \mathrm{G}$ & Leu - Ser & C & $\mathrm{T}$ & $\mathrm{T}$ \\
\hline & 509 & $A(A / T) G$ & Lys - Met & A & $\mathrm{T}$ & A \\
\hline & 626 & $\mathrm{GA}(\mathrm{A} / \mathrm{C})$ & Glu - Asp & C & A & A \\
\hline & 690 & $\mathrm{CA}(\mathrm{G} / \mathrm{C})$ & Gln - His & C & G & G \\
\hline & 796 & $(\mathrm{~A} / \mathrm{T}) \mathrm{GC}$ & Ser - Cys & $\mathrm{T}$ & A & A \\
\hline & 1,018 & $(\mathrm{G} / \mathrm{T}) \mathrm{CC}$ & Ala - Ser & $\mathrm{T}$ & G & G \\
\hline & 1,067 & $C(A / G) G$ & Gln - Arg & A & G & A \\
\hline \multirow[t]{7}{*}{$\mathrm{F} 3^{\prime} \mathrm{H}$} & 35 & $\mathrm{G}(\mathrm{C} / \mathrm{G}) \mathrm{C}$ & Ala - Gly & G & C & $C / G$ \\
\hline & 61 & $(\mathrm{~T} / \mathrm{A}) \mathrm{TA}$ & Leu - Ile & A & $\mathrm{T}$ & $\mathrm{A} / \mathrm{T}$ \\
\hline & 92 & $\mathrm{C}(\mathrm{C} / \mathrm{G})(\mathrm{T} / \mathrm{C})$ & Pro - Arg & CGT & $\mathrm{CCT}$ & $\mathrm{C}(\mathrm{G} / \mathrm{C})(\mathrm{C} / \mathrm{T})$ \\
\hline & 115 & $(\mathrm{~T} / \mathrm{C}) \mathrm{GG}$ & Trp - Arg & C & $\mathrm{T}$ & $\mathrm{C} / \mathrm{T}$ \\
\hline & 790 & $(\mathrm{C} / \mathrm{A})(\mathrm{G} / \mathrm{T}) \mathrm{T}$ & Agr - Ile - Ser & ATT & CGT & $A(G / T) T$ \\
\hline & 863 & $\mathrm{G}(\mathrm{G} / \mathrm{A}) \mathrm{A}$ & Agr - Glu & G & G & $A / G$ \\
\hline & 1,243 & $(C / A) T A$ & Leu - Ile & A & C & C \\
\hline DFR & 901 & $(A / G) A G$ & Lys - Glu & G & A & A \\
\hline
\end{tabular}

Table 3 Characteristics of non-synonymous SNPs of 12 genes of the phenylpropanoid-flavonoid pathways in three mango varieties (Continued)

\begin{tabular}{|c|c|c|c|c|c|c|}
\hline \multirow[t]{2}{*}{ ANS } & 169 & $\mathrm{GA}(\mathrm{G} / \mathrm{C})$ & Glu - Asp & G & C & G \\
\hline & 633 & $\mathrm{G}(\mathrm{G} / \mathrm{A}) \mathrm{G}$ & Arg - Glu & G & A & G \\
\hline \multirow[t]{10}{*}{ ANR } & 49 & $(\mathrm{~A} / \mathrm{G}) \mathrm{CC}$ & Ala - Thr & $A / G$ & A & A \\
\hline & 68 & $\mathrm{~T}(\mathrm{~T} / \mathrm{G}) \mathrm{G}$ & Leu - Trp & $\mathrm{G} / \mathrm{T}$ & $\mathrm{T}$ & $\mathrm{T}$ \\
\hline & 128 & $\mathrm{G}(\mathrm{A} / \mathrm{G}) \mathrm{T}$ & Asp - Arg & A & A & G \\
\hline & 136 & $(\mathrm{C} / \mathrm{A}) \mathrm{AA}$ & Gln - Lys & $C$ & C & A \\
\hline & 172 & $(\mathrm{G} / \mathrm{T}) \mathrm{GT}$ & Cys - Arg & $\mathrm{T} / \mathrm{G}$ & G & G \\
\hline & 226 & $(\mathrm{C} / \mathrm{T}) \mathrm{CT}$ & Cys - Pro & $\mathrm{T} / \mathrm{C}$ & C & C \\
\hline & 329 & $\mathrm{G}(\mathrm{A} / \mathrm{G}) \mathrm{G}$ & Glu - Agr & A & A & G \\
\hline & 506 & $\mathrm{G}(\mathrm{T} / \mathrm{C}) \mathrm{C}$ & Val - Ala & $\mathrm{T}$ & $\mathrm{T}$ & C \\
\hline & 552 & $\mathrm{GA}(\mathrm{G} / \mathrm{T})$ & Glu - Asp & G & G & $\mathrm{T}$ \\
\hline & 653 & $\mathrm{~T}(\mathrm{~T} / \mathrm{A}) \mathrm{A}$ & Leu - Ser & T & $\mathrm{T} / \mathrm{C}$ & C \\
\hline
\end{tabular}

Transcriptional profiles of genes involved in biosynthesis of phenolic compounds in mango fruit

We used quantitative, reverse-transcription PCR (RT-PCR) to assess potential correlations between the expression of PF genes and the differences in chemical profiles of KP, IW and NDM. The expression patterns of the phenylpropanoid biosynthetic genes (PAL, $\mathrm{C} 4 \mathrm{H})$ and genes involved in the biosynthesis of various flavonoids (4CL, C3' $\mathrm{H}, \mathrm{CHS1}$, CHS2, F3H1, F3H2, F3'H, DFR, ANS and ANR) were examined in mango peel and flesh of ripe fruits with actin as an endogenous reference gene.

Transcript levels of PF upstream genes differed significantly between mango peel and flesh. The expression of PAL gene in KP peel was approximately 45 -fold higher than in the respective KP flesh, 30-fold higher in IW peel than flesh, and 12-fold higher in NDM peel than flesh, when expression was normalised to actin gene expression (Fig. 3). The expression of $\mathrm{C} 4 \mathrm{H}$ and $\mathrm{CHS}$ genes in $\mathrm{KP}$ and IW peels were significantly $(P<0.01)$ higher than in flesh when expression was normalized to actin housekeeping gene (Fig. 3). There was no significant difference in the expression of $\mathrm{C} 4 \mathrm{H}$ and $\mathrm{CHS}$ genes between NDM peel and flesh, indicating significant differences between varieties. PAL mediates carbon flux into the phenylpropanoid pathway to produce cinnamic acid, the substrate for the next step mediated by $\mathrm{C} 4 \mathrm{H}$ (Fig. 1). These steps represent the connection between primary and secondary metabolism while the first committed step of the flavonoid biosynthesis pathway is mediated by CHS. Our previous studies have demonstrated that soluble polyphenolic contents expressed as gallic acid equivalents (GAE) in mango peel extracts varied between 634 and $868 \mathrm{mg}$ (GAE) per g dry weight, and were higher than flesh extracts (181- $304 \mathrm{mg}$ GAE per g dry weight) [33]. This study provides evidence of a 

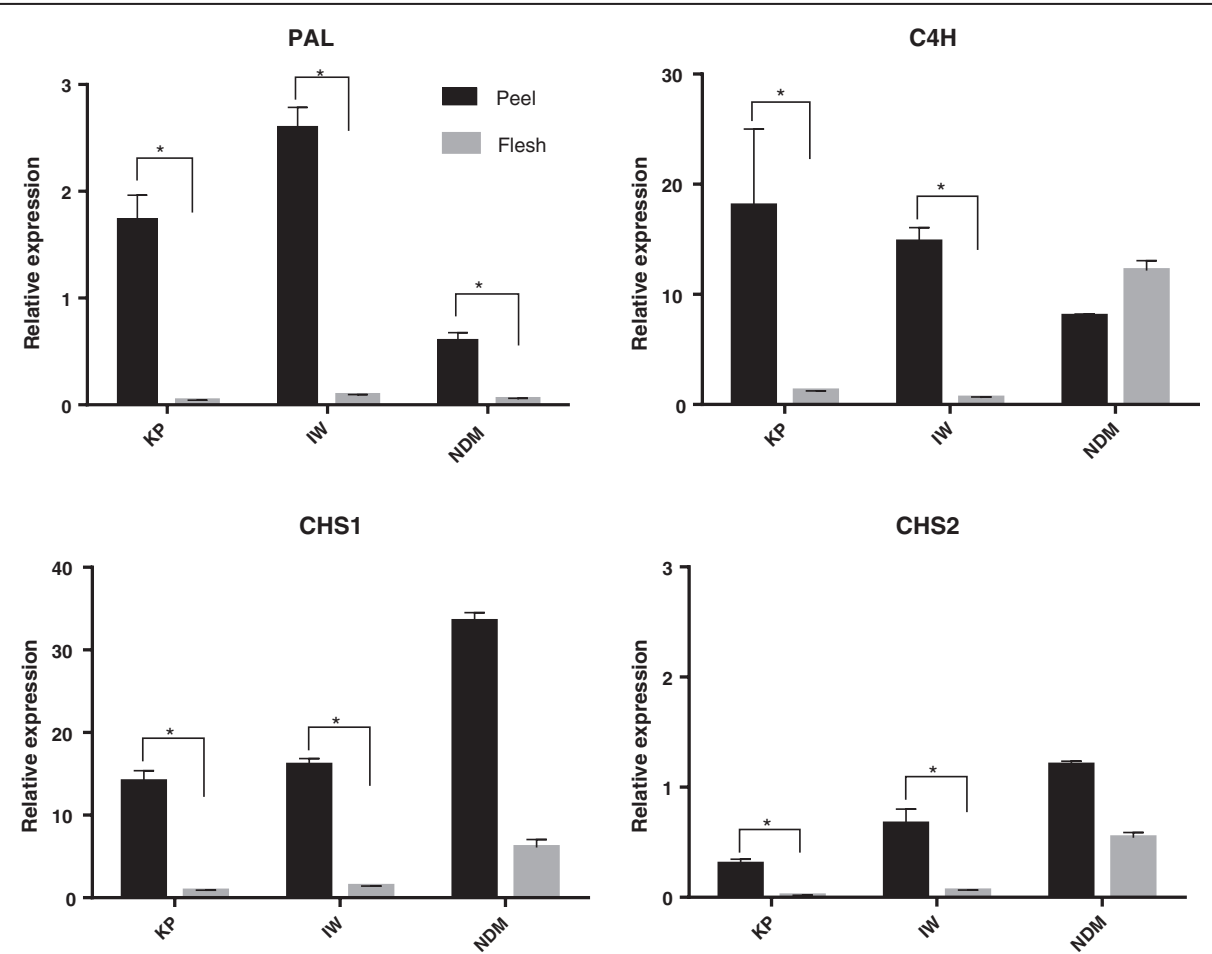

Fig. 3 Relative expression levels of PAL, C4H and CHSs mRNAs in mango peel (black) and flesh (grey) determined by Real-time RT-PCR. For all panels the data represent mean \pm SEM relative to the Actin control $(n=3, * P<0.01)$

coordinated up-regulation of up-stream biosynthesis pathway genes leading to high accumulation of phenolic compounds in mango peel. Similar patterns have been reported in tomato, where the expression of the upstream flavonoid biosynthesis genes including PAL and CHS exhibited significant correlation with accumulation of flavonoid compounds in peel; and only low levels of flavonoid-related transcripts were detected in the flesh $[42,43]$.

Previous studies of gene expression in temperate fruits reported two peaks of flavonoid activity during fruit ripening, one in green fruit and the other in nearly ripe fruit [44-46]. In our mango study, the expression of 12 PF biosynthetic genes was detected in all mango peels at the ripe stage. Remarkably, a significant difference in transcript levels between varieties was observed for ANR (Fig. 4). Roles of CHS, F3H, DFR and ANS in the anthocyanin biosynthetic pathway have been reported in fruit plants such as olive, cacao and grape [7, 47, 48]. Additionally, some studies in green tea [49] and temperate fruits including apple, grape, and strawberry implied important roles of ANR in PA biosynthesis [50, 51]. In grape, the expression of ANS and ANR were co-regulated which showed their contribution to PA synthesis in fruit [52]. The over-expression of ANR in the Arabidopsis banyuls (anr) mutant restored PA synthesis in seeds [53]. During strawberry fruit development, the expression pattern of
ANR was correlated with epicatechin production [50]. However, the expression pattern for ANR differed from plant tissues and fruit development $[52,54]$. In this study, the ANR transcript level in IW was 8-fold lower than in KP and 12-fold lower than in NDM. There was no significant different in the expression of ANS in three mango varieties. A qualitative biochemical analysis among the three mango varieties demonstrated the presence of ECG in KP and NDM peel extracts but not in IW peel extract [13]. ANR is ultimately responsible for the biosynthesis of epicatechin and related compounds such as ECG (Fig. 1). Taken together, these results suggest an association between the higher expression of ANR genes in KP and NDM with the accumulation of ECG in extracts of these two mango varieties. It should be noted however that our study only analysed ripe stage fruits. The expression of genes involved in the phenylpropanoid flavonoid metabolism in peel and flesh tissues of KP, NDM and IW fruits were summarised and visualised by MapMan (Fig. 5).

\section{Conclusions}

Our study shows that it is possible to discover candidate genes for many mango PF biosynthetic pathway enzymes through use of a mango fruit EST library. Phylogenetic analysis of pathway genes revealed a close evolutionary relationship between mango, $P$. trichocarpa and $V$. vinifera. 


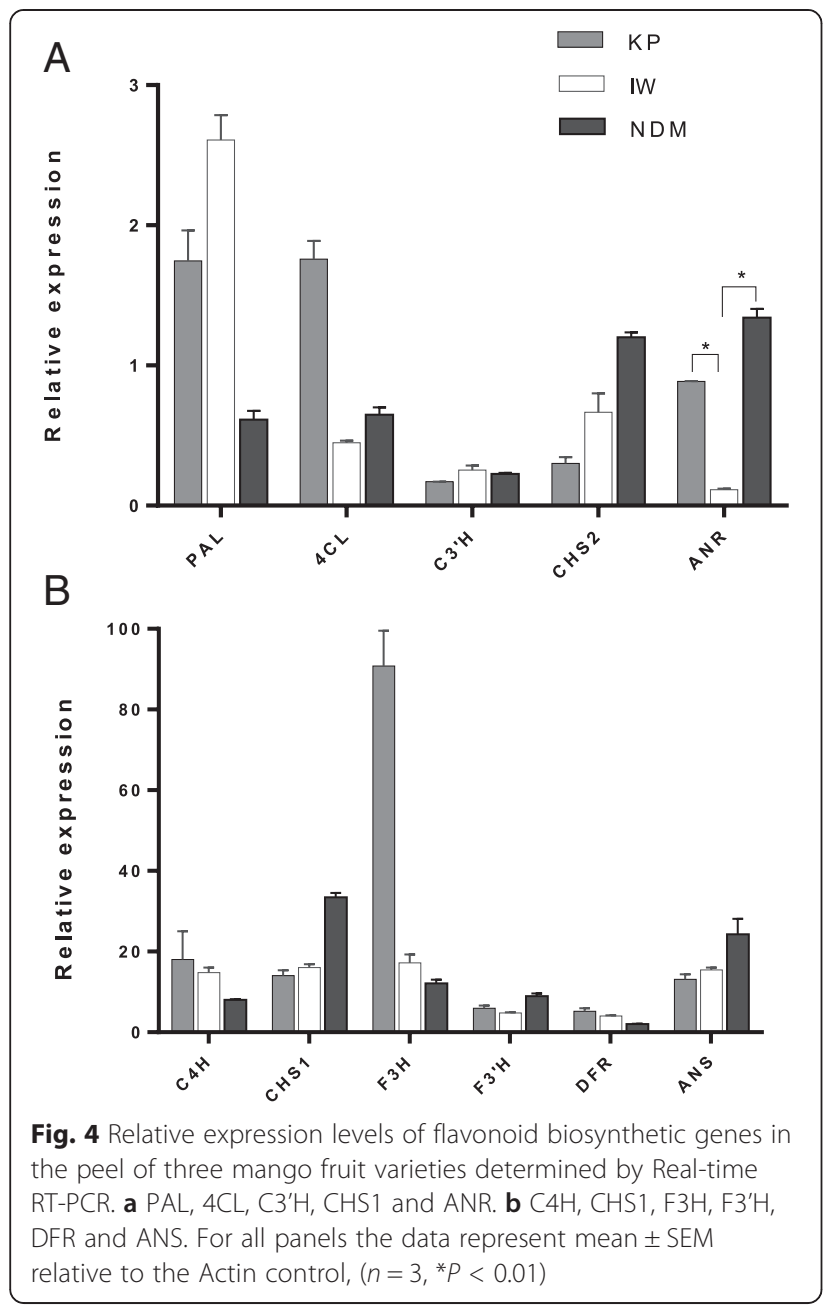

This study has determined, for the first time, the SNP frequency in coding sequences of PF biosynthetic genes of KP, IW and NDM mangoes. This study established a positive relationship between total phenolic content and expression levels of PAL, C4H and CHS in mango fruit. The high expression of anthocyanin-related gene, ANR in KP and NDM peel compared to IW peel may explain the presence of ECG in KP and NDM peels, but its absence in IW peel. Further study could examine the possible association of the identified SNPs with expression differences. This combined knowledge will facilitate future breeding and selection of new mango varieties possessing tailored bioactive compound profiles with properties beneficial to health.

\section{Methods}

\section{Preparation of mango fruit}

KP, IW and NDM were provided by Dr Ian Bally from the Department of Agriculture and Fisheries' Southedge Research Station, Queensland, Australia and left to rest at $20{ }^{\circ} \mathrm{C}$ until they reached consumption ripeness as assessed by the sprung test [55] with some modification
[12]. Fruits of each variety were collected from the same tree. The ripe fruits were cleaned with water and the seeds removed. The peel and flesh were then stored at $-80{ }^{\circ} \mathrm{C}$ until total RNA was extracted.

\section{RNA extraction and CDNA synthesis}

Total RNA was extracted using the cetyltrimethyl ammonium bromide (CTAB) method described by Chang et al. [56] with some minor modifications. Spermidine was omitted and only $1 \% 2$-mercaptoethanol was used. All solutions used in RNA extractions were treated with $0.1 \% \mathrm{v} / \mathrm{v}$ diethyl pyrocarbonate (DEPC) and autoclaved to inactivate RNases. Ten $\mathrm{mL}$ of extraction buffer (2\% CTAB, $2.5 \%$ polyvinylpolypyrrolidone, $2 \mathrm{M} \mathrm{NaCl}$, $100 \mathrm{mM}$ Tris- $\mathrm{HCl} \mathrm{pH} 8.0,25 \mathrm{mM}$ EDTA pH 8.0 and $2 \%$ of 2-mercaptoethanol added just before use) was heated at $65{ }^{\circ} \mathrm{C}$ in $50 \mathrm{~mL}$ tubes. Samples were extracted from three replicates, each replicate from three pooled mature fruits of each mango variety. The flesh or peel of pooled mango fruits $(1 \mathrm{~g})$, powdered in liquid nitrogen using a mortar and pestle, was added to the extraction buffer and the tube was incubated at $65^{\circ} \mathrm{C}$ for $10 \mathrm{~min}$. An equal volume of chloroform was added and the tube was inverted vigorously and centrifuged at $10,000 \mathrm{~g}$ for $10 \mathrm{~min}$ at $4{ }^{\circ} \mathrm{C}$. Total RNA was precipitated by addition of 1 volume of $10 \mathrm{M} \mathrm{LiCl}$ to the supernatant. The mixture was incubated at $4{ }^{\circ} \mathrm{C}$ overnight and RNA was selectively pelleted by centrifugation at $10,000 \mathrm{~g}$ for $40 \mathrm{~min}$ at $4{ }^{\circ} \mathrm{C}$. The pellet was resuspended in $5 \mathrm{~mL}$ of $70 \%$ ethanol and the mixture was centrifuged at $10,000 \mathrm{~g}$ for $5 \mathrm{~min}$ at $4{ }^{\circ} \mathrm{C}$, dried and resuspended in DEPC-treated water. RNA concentrations were determined using a NanoDrop ${ }^{\circ}$ ND-1000 Spectrophotometer (Thermo Scientific), and the quality was confirmed on $1.2 \%$ agarose gel using TAE buffer. RNA samples were treated with TURBO ${ }^{\mathrm{mm}}$ DNase (Ambion) in accordance with the manufacturer's instruction and stored at $-80{ }^{\circ} \mathrm{C}$. About $1 \mu \mathrm{g}$ of total RNA was reversetranscribed by use of Superscript III First-strand Synthesis Mix (Invitrogen) with oligo $(\mathrm{dT})_{20}$ primer in accordance with the manufacturer's protocol.

\section{Gene discovery}

Information on selected biosynthesis genes in mango (Fig. 1) was obtained from ESTs present in the Mango Genomics Database (http://mango.qfab.org), a proprietary database containing nucleotide sequence, phenotypic, and sensory information for mango. Sequence contig assemblies were used as initial source for analyses. Full-length EST sequences were obtained using M13 Forward (-20) and Reverse primers. Sanger sequencing was performed using Applied Biosystems 3730xI capillary sequencers by the Australian Genome Research Facility (AGRF, St Lucia, QLD, Australia). Nucleotide sequences from three colonies each were analysed using the Geneious v.5.1 (Biomatters, 


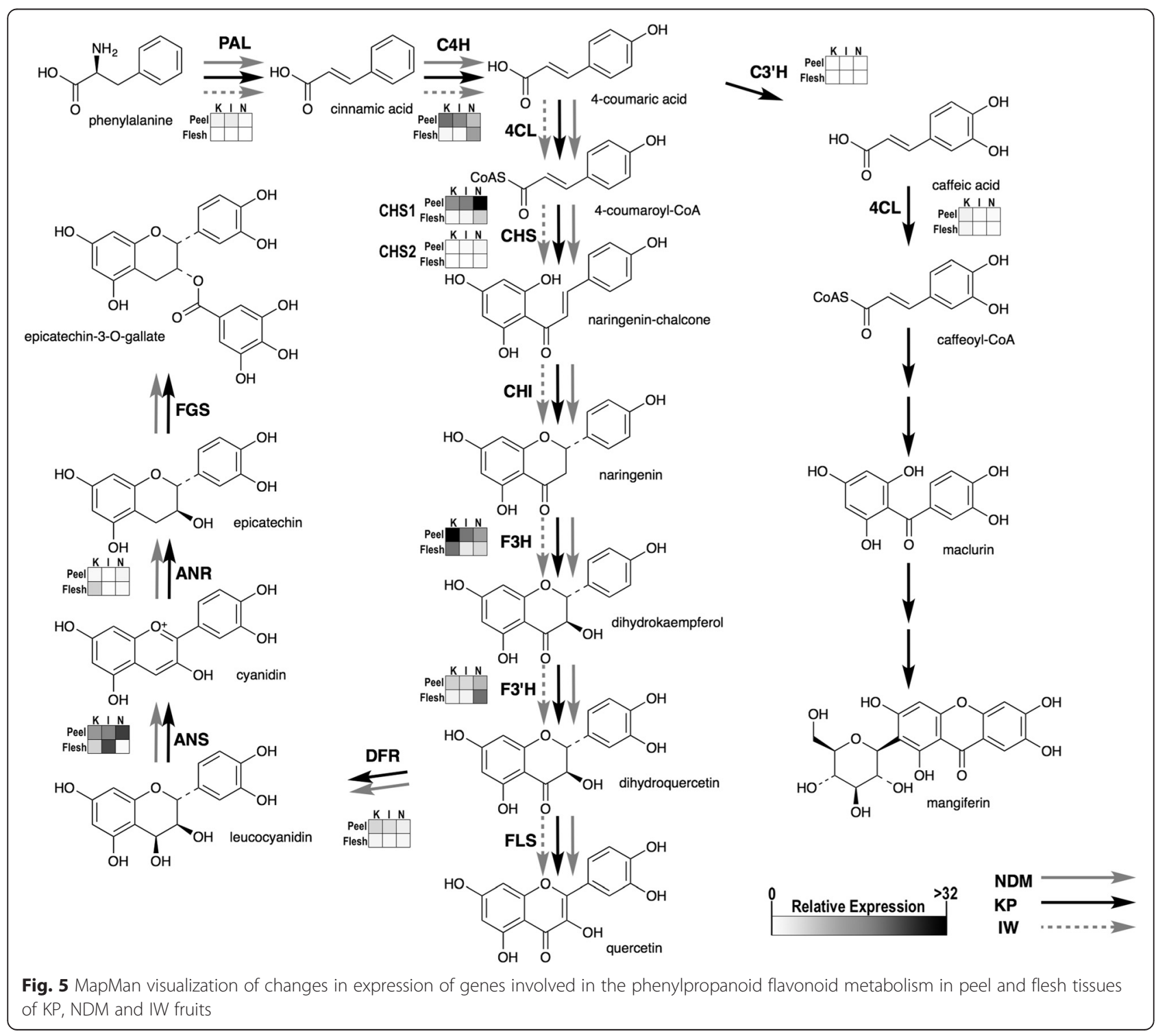

New Zealand) [57]. The amino acid sequences generated from the consensus sequences were compared using BLAST-P (http://blast.ncbi.nlm.nih.gov/Blast.cgi) [58] with default parameters against reference sequences available on the NCBI nucleotide databases ( $e$-value $\leq 10^{-5}$ ) to confirm identities. All sequences were aligned using Geneious default values, with pair-wise parameters set at gap opening penalty 10 , gap extension penalty 0.1 and multiple alignment parameters set at gap opening penalty of 10, gap extension 0.2. Sequences were deposited in GenBank with accession numbers shown in Table 1.

Primers were designed based on the open reading frames of all mango candidate genes identified from ESTs with default settings on the Primer feature in Geneious [59]. Primers were synthesised by Geneworks (Adelaide,
Australia) (Additional file 1) and yielded expected amplicons with KP, IW and NDM cDNA. Fragments were amplified by PCR with Phusion HF (Finnzymes) using conditions recommended by the manufacturer, separated on $1.2 \%$ agarose gels containing ethidium bromide with images captured on a Geldoc system (BioRad). PCR products were gel-purified using a Wizard ${ }^{\circ}$ SV gel purification kit (Promega), ligated into $\mathrm{PCR}^{\mathrm{m}} 4$ Blunt-TOPO vector (Invitrogen) and transformed into TOP10 competent cells (Invitrogen). Recombinant colonies were grown at $37{ }^{\circ} \mathrm{C}$ overnight on LB-Ampicillin $(50 \mu \mathrm{g} / \mathrm{mL})$ agar plates. Plasmid DNA was extracted from overnight liquid cultures using the GeneJET ${ }^{\mathrm{m}}{ }^{\mathrm{m}}$ Plasmid Miniprep kit (Fermentas), quantified using a NanoDrop ${ }^{\circ}$ and sequenced using M13 forward and reverse primers. 


\section{Comparison of amino acid sequences and phylogenetic analyses}

Amino acid sequences were aligned in Geneious using global alignment with default parameters [57]. Searches for homologous sequences were conducted using the BLAST$\mathrm{P}$ module. To investigate the evolutionary relationships of candidate mango flavonoid pathway proteins to homologous proteins described from other plant species, phylogenetic trees were constructed using parsimony and/or genetic distance calculations Neighbour-joining and Bootstrap with 1000 replicates.

\section{Quantitative real-time PCR}

Real-time RT-PCR was done in a RotorGene RG-6000 Thermal Cycler (Qiagen) to determine relative gene expression levels in peel and flesh of KP, IW and NDM fruits with actin (GenBank accession number HQ830244) as an endogenous reference gene $[34,60]$ with three independent biological replicates (three technical replicates for each sample) using Rotor-Gene SYBR Green PCR Kit (Qiagen). All primers were designed from available mango candidate gene sequences, with the Primer feature in Geneious [59] (S1) and verified by Netprimer software. Primers were synthesised by Geneworks. PCR conditions were $95{ }^{\circ} \mathrm{C}$ for 5 min followed by 40 cycles of $95^{\circ} \mathrm{C}$ for $5 \mathrm{~s}$ and combined annealing/extension $60{ }^{\circ} \mathrm{C}$ for 10 s. Amplification was followed by a melting curve analysis with continual fluorescence data acquisition during the $60-95{ }^{\circ} \mathrm{C}$ melt. A no template control was included in each experiment. Expression values were normalized to the endogenous actin control by calculating the $\Delta \mathrm{Ct}(\Delta \mathrm{Ct}=\mathrm{Ct}$ target gene $-\mathrm{Ct}$ endogenous control). Data are presented as fold changes, using $2^{-\Delta C t}$ [61-63]. Changes of mango genes expression were analysed by MapMan software (http://mapman.gabipd.org, version 3.5.1) [64].

\section{Statistical analysis}

Statistical analysis was done with GraphPad PRISM 5 (GraphPad Software, San Diego, USA). Significance was determined using one-way analysis of variance with the Tukey's test for all pairwise multiple comparisons for normally distributed data of equal variance. Standard deviations of $\Delta \mathrm{Ct}$ values were calculated from measurements performed in triplicate.

\section{Additional file}

Additional file 1: List of primers used for quantitative reverse transcription-polymerase chain reaction. (DOCX $32 \mathrm{~kb}$ )

\section{Abbreviations}

4CL: 4-coumarate:CoA ligase; ANR: Anthocyanidin reductase; ANS: Anthocyanidin synthase; C3'H: p-coumaroyl ester 3'-hydroxylase; $\mathrm{C} 4 \mathrm{H}$ : Cinnamate 4-mono-oxygenase; CHI: Chalcone isomerase; CHS: Chalcone synthases; DFR: Dihydroflavonol 4-reductases; EST: Expressed sequence tag;
F3H: Flavanone 3-hydroxylase; F3'H: Flavonoid 3'-hydroxylase; FGS: Flavan-3ol-gallate synthase; FLS: Flavone synthase; GAE: Gallic acid equivalents; KP: Kensington Pride; IW: Irwin; NDM: Nam Doc Mai; PA: Proanthocyanidin; PAL: Phenylalanine ammonia lyase; PF: Phenylpropanoid-flavonoid; SNP: Single nucleotide polymorphisms.

\section{Competing interests}

The authors declare that they have no competing interests.

\section{Authors' contributions}

$\mathrm{VH}$ was responsible for RNA extractions, carried out studies and drafted the manuscript. DI and RD participated in the sequence alignment and in the design of the study. GM, NS, RD and MG coordinated the study. All authors read, edited and approved the final manuscript.

\section{Acknowledgements}

We thank the Queensland Department of Agriculture and Fisheries for access to the Mango Genomics Database and Dr lan Bally for provision of mango fruit varieties from the Australian National Mango Genbank. This work was supported by the University of Queensland and Australian Research Council Linkage project LP0883644.

\section{Author details}

${ }^{1}$ School of Pharmacy, The University of Queensland, Brisbane, Queensland, Australia. ${ }^{2}$ Centre for Nutrition and Food Sciences, Queensland Alliance for Agriculture and Food Innovation, The University of Queensland, Brisbane, Queensland, Australia. ${ }^{3}$ Department of Agriculture and Fisheries, Agri-Science Queensland, Brisbane, Queensland, Australia.

Received: 8 February 2015 Accepted: 17 July 2015

Published online: 30 July 2015

\section{References}

1. Middleton Jr E, Kandaswami C, Theoharides TC. The effects of plant flavonoids on mammalian cells: implications for inflammation, heart disease, and cancer. Pharmacol Rev. 2000;52(4):673-751.

2. Burbulis IE, Winkel-Shirley B. Interactions among enzymes of the Arabidopsis flavonoid biosynthetic pathway. Proc Natl Acad Sci U S A. 1999;96(22):12929-34.

3. de Vries GE. Flavonoid biosynthetic pathway. Trends Plant Sci. 2000;5(1):7.

4. Cohen SD, Tarara JM, Gambetta GA, Matthews MA, Kennedy JA. Impact of diurnal temperature variation on grape berry development, proanthocyanidin accumulation, and the expression of flavonoid pathway genes. J Exp Bot. 2012;63(7):2655-65.

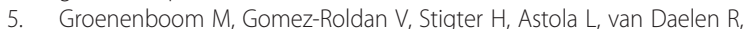
Beekwilder J, et al. The flavonoid pathway in tomato seedlings: transcript abundance and the modeling of metabolite dynamics. PLOS ONE. 2013;8(7):e68960.

6. Saito K, Yonekura-Sakakibara K, Nakabayashi R, Higashi Y, Yamazaki M, Tohge T, et al. The flavonoid biosynthetic pathway in Arabidopsis: Structural and genetic diversity. Plant Physiol Biochem. 2013;72:21-34.

7. Galla G, Barcaccia G, Ramina A, Collani S, Alagna F, Baldoni L, et al. Computational annotation of genes differentially expressed along olive fruit development. BMC Plant Biol. 2009:9:128-45.

8. Martinelli F, Tonutti P. Flavonoid metabolism and gene expression in developing olive (Olea europaea L.) fruit. PI Biosyst. 2012:146:164-70.

9. Bally ISE, Lu P, Johnson PR. Mango breeding. In: Jain SM, Priyadarshan PM, editors. Breeding Plantation Tree Crops: Tropical Species. New York, USA: Springer; 2009. p. 51-82

10. Bally ISE. Advances in Research and Development of Mango Industry. Rev Bras Frutic. 2011:33:57-63.

11. Masibo M, He Q. Mango bioactive compounds and related nutraceutical properties. Food Rev Int. 2009:25:346-70.

12. Taing MW, Pierson JT, Hoang VL, Shaw PN, Dietzgen RG, Gidley MJ, et al. Mango fruit peel and flesh extracts affect adipogenesis in 3T3-L1 cells. Food Funct. 2012;3:828-36.

13. Pierson JT, Monteith GR, Roberts-Thomson SJ, Dietzgen RG, Gidley MJ, Shaw PN. Phytochemical extraction, characterisation and comparative distribution across four mango (Mangifera indica L.) fruit varieties. Food Chem. 2014;149:253-63 
14. Hossain MA, Rana MM, Kimura Y, Roslan HA. Changes in biochemical characteristics and activities of ripening associated enzymes in mango fruit during the storage at different temperatures. BioMed Res Int. 2014;2014:232969.

15. Palafox-Carlos H, Contreras-Vergara CA, Muhlia-Almazan A, Islas-Osuna MA, Gonzalez-Aguilar GA. Expression and enzymatic activity of phenylalanine ammonia-lyase and p-coumarate 3-hydroxylase in mango (Mangifera indica 'Ataulfo') during ripening. Genet Mol Res. 2014;13(2):3850-8.

16. Ish-Shalom M, Dahan Y, Maayan I, Irihimovitch V. Cloning and molecular characterization of an ethylene receptor gene, MiERS1, expressed during mango fruitlet abscission and fruit ripening. Plant Physiol Biochem. 2011;49(8):931-6.

17. Chidley HG, Kulkarni RS, Pujari KH, Giri AP, Gupta VS. Spatial and temporal changes in the volatile profile of Alphonso mango upon exogenous ethylene treatment. Food Chem. 2013;136(2):585-94.

18. Joulain D. J Agric Food Chem. 2005;53(21):8418. author reply 8419.

19. Ornelas-Paz JD, Yahia EM, Gardea AA. Changes in external and internal color during postharvest ripening of 'Manila' and 'Ataulfo' mango fruit and relationship with carotenoid content determined by liquid chromatography-APcl(+)-time-of-flight mass spectrometry. Postharvest Biol Technol. 2008;50:145-52.

20. Pandit SS, Kulkarni RS, Giri AP, Kollner TG, Degenhardt J, Gershenzon J, et al. Expression profiling of various genes during the fruit development and ripening of mango. Plant Physiol Biochem. 2010;48(6):426-33.

21. Wu HX, Jia HM, Ma XW, Wang SB, Yao QS, Xu WT, et al. Transcriptome and proteomic analysis of mango (Mangifera indica Linn) fruits. J Proteomics. 2014:105:19-30.

22. Azim MK, Khan IA, Zhang Y. Characterization of mango (Mangifera indica L.) transcriptome and chloroplast genome. Plant Mol Biol. 2014;85(1-2):193-208.

23. Luria N, Sela N, Yaari M, Feygenberg O, Kobiler I, Lers A, et al. De-novo assembly of mango fruit peel transcriptome reveals mechanisms of mango response to hot water treatment. BMC Genomics. 2014;15:957.

24. Clotault J, Peltier D, Soufflet-Freslon V, Briard M, Geoffriau E. Differential selection on carotenoid biosynthesis genes as a function of gene position in the metabolic pathway: a study on the carrot and dicots. PLOS ONE. 2012;7(6), e38724.

25. Guerra R, Yu Z. Single Nucleotide Polymorphisms and Their Applications. In: Zhang W, Shmulevich I, editors. Computational and Statistical Approaches to Genomics. US: Springer; 2006. p. 311-49.

26. Brookes AJ. The essence of SNPs. Gene. 1999;234(2):177-86.

27. Ganal MW, Altmann T, Roder MS. SNP identification in crop plants. Curr Opin Plant Biol. 2009;12(2):211-7.

28. Aguade M. Nucleotide sequence variation at two genes of the phenylpropanoid pathway, the FAH1 and F3H genes, in Arabidopsis thaliana. Mol Biol Evol. 2001;18(1):1-9.

29. Andersen JR, Zein I, Wenzel G, Darnhofer B, Eder J, Ouzunova M, et al. Characterization of phenylpropanoid pathway genes within European maize (Zea mays L.) inbreds. BMC Plant Biol. 2008;8:2-16.

30. Kota R, Rudd S, Facius A, Kolesov G, Thiel T, Zhang H, et al. Snipping polymorphisms from large EST collections in barley (Hordeum vulgare L.). Mol Genet Genomics. 2003;270(1):24-33.

31. Dillon NL, Bally ISE, Wright CL, Hucks L, Innes DJ, Dietzgen RG. Genetic diversity of the Australian National Mango Genebank. Sci Hort. 2013;150:213-26.

32. Rajendran $P$, Ekambaram $G$, Sakthisekaran D. Effect of mangiferin on benzo(a)pyrene induced lung carcinogenesis in experimental Swiss albino mice. Nat Prod Res. 2008;22:672-80.

33. Hoang VLT, Pierson J-T, Curry MC, Shaw PN, Dietzgen RG, Gidley MJ, et al. Polyphenolic contents and the effects on breast cancer cells of methanolic extracts from various mango varieties. Food Sci Biotechnol. 2014, Accepted.

34. Lou C, He X-H, H C, Hu Y, Ou S-J. Molecular cloning and expression analysis of four actin genes (MiACT) from mango. Bio Plantarum. 2013. 57:238-44.

35. Gilchrist EJ, Haughn GW, Ying CC, Otto SP, Zhuang J, Cheung D, et al. Use of Ecotilling as an efficient SNP discovery tool to survey genetic variation in wild populations of Populus trichocarpa. Mol Ecol. 2006;15:1367-78.

36. Van K, Hwang EY, Kim MY, Kim YH, Cho Yl, Cregan PB, et al. Discovery of single nucleotide polymorphisms in soybean using primers designed from ESTs. Euphytica. 2004;139:147-57.

37. Krzywinski M, Schein J, Birol I, Connors J, Gascoyne R, Horsman D, et al. Circos: an information aesthetic for comparative genomics. Genome Res. 2009;19(9):1639-45.
38. Chagne D, Crowhurst RN, Troggio M, Davey MW, Gilmore B, Lawley C, et al. Genome-wide SNP detection, validation, and development of an 8K SNP array for apple. PLoS ONE. 2012;7(2), e31745.

39. Lu Y, Rausher MD. Evolutionary rate variation in anthocyanin pathway genes. Mol Biol Evol. 2003;20(11):1844-53.

40. Livingstone $\mathrm{K}$, Anderson S. Patterns of variation in the evolution of carotenoid biosynthetic pathway enzymes of higher plants. J Hered. 2009;100(6):754-61.

41. Chagne D, Gasic K, Crowhurst RN, Han Y, Bassett HC, Bowatte DR, et al. Development of a set of SNP markers present in expressed genes of the apple. Genomics. 2008;92(5):353-8.

42. Adato A, Mandel T, Mintz-Oron S, Venger I, Levy D, Yativ M, et al. Fruit-Surface Flavonoid Accumulation in Tomato Is Controlled by a SIMYB12-Regulated Transcriptional Network. PLoS Genet. 2009;5:1-23.

43. Verhoeyen ME, Bovy A, Collins G, Muir S, Robinson S, de Vos $\mathrm{CH}$, et al. Increasing antioxidant levels in tomatoes through modification of the flavonoid biosynthetic pathway. J Exp Bot. 2002;53(377):2099-106.

44. Cheng GW, Breen PJ. Activity of phenylalanine ammonia-lyase (PAL) and concentrations of anthocyanins and phenolics in developing strawberry fruit. J Am Soc Hortic Sci. 1991;116:865-9.

45. Singh R, Rastogi S, Dwivedi UN. Phenylpropanoid Metabolism in Ripening Fruits. Compr Rev Food Sci Food Saf. 2010;9:398-416.

46. Salvatierra A, Pimentel P, Moya-Leon MA, Caligari PDS, Herrera R. Comparison of transcriptional profiles of flavonoid genes and anthocyanin contents during fruit development of two botanical forms of Fragaria chiloensis ssp. chiloensis. Phytochemistry. 2010;71:1839-47.

47. Boss PK, Davies C, Robinson SP. Analysis of the Expression of Anthocyanin Pathway Genes in Developing Vitis vinifera L. cv Shiraz Grape Berries and the Implications for Pathway Regulation. Plant Physiol. 1996;111(4):1059-66.

48. Liu Y, Shi Z, Maximova S, Payne MJ, Guiltinan MJ. Proanthocyanidin synthesis in Theobroma cacao: genes encoding anthocyanidin synthase, anthocyanidin reductase, and leucoanthocyanidin reductase. BMC Plant Biol. 2013;13:202

49. Ashihara H, Deng WW, Mullen W, Crozier A. Distribution and biosynthesis of flavan-3-ols in Camellia sinensis seedlings and expression of genes encoding biosynthetic enzymes. Phytochemistry. 2010;71(5-6):559-66.

50. Xiaonan Z, Qing C, Dingqun Y, Shuli Z, Haoru T. Expression Analysis of the ANR and LAR Gene in Fragaria $\times$ ananassa cV. Toyonaka J Agr Sci. 2013;5(2):64-9.

51. Pfeiffer J, Kuhnel C, Brandt J, Duy D, Punyasiri PA, Forkmann G, et al Biosynthesis of flavan 3-ols by leucoanthocyanidin 4-reductases and anthocyanidin reductases in leaves of grape (Vitis vinifera L.), apple (Malus $x$ domestica Borkh.) and other crops. Plant Physiol Biochem. 2006:44(5-6):323-34.

52. Bogs J, Downey MO, Harvey JS, Ashton AR, Tanner GJ, Robinson SP. Proanthocyanidin synthesis and expression of genes encoding leucoanthocyanidin reductase and anthocyanidin reductase in developing grape berries and grapevine leaves. Plant Physiol. 2005;139(2):652-63.

53. Devic M, Guilleminot J, Debeaujon I, Bechtold N, Bensaude E, Koornneef M, et al. The BANYULS gene encodes a DFR-like protein and is a marker of early seed coat development. Plant J. 1999;19(4):387-98.

54. Fujita A, Goto-Yamamoto N, Aramaki I, Hashizume K. Organ-specific transcription of putative flavonol synthase genes of grapevine and effects of plant hormones and shading on flavonol biosynthesis in grape berry skins. Biosci Biotechnol Biochem. 2006;70(3):632-8.

55. Malik AU, Singh Z. Pre-storage application of polyamines improves shelf-life and fruit quality in mango. J Hortic Sci Biotech. 2005;80:363-9.

56. Chang S, Puryear J, Cairney J. A simple and effcient method for isolating RNA from pine trees. Plan Mol Biol Rep. 1993;11:113-6.

57. Kearse M, Moir R, Wilson A, Stones-Havas S, Cheung M, Sturrock S, et al. Geneious Basic: an integrated and extendable desktop software platform for the organization and analysis of sequence data. Bioinformatics 2012; 28(12): 1647-1649.

58. Altschul SF, Gish W, Miller W, Myers EW, Lipman DJ. Basic local alignment search tool. J Mol Biol. 1990;215:403-10.

59. Rozen S, Skaletsky H. Primer3 on the WWW for general users and for biologist programmers. Methods Mol Biol. 2000;132:365-86.

60. Singh RK, Ali SA, Nath P, Sane VA. Activation of ethylene-responsive p-hydroxyphenylpyruvate dioxygenase leads to increased tocopherol levels during ripening in mango. J Exp Bot. 2011;62(10):3375-85. 
61. Devitt LC, Fanning K, Dietzgen RG, Holton TA. Isolation and functional characterization of a lycopene b-cyclase gene that controls fruit colour of papaya (Carica papaya L.). J Exp Bot. 2010;61:33-9.

62. Giuntini D, Lazzeri V, Calvenzani V, Dall'Asta C, Galaverna G, Tonelli C, et al. Flavonoid profiling and biosynthetic gene expression in flesh and peel of two tomato genotypes grown under UV-B-depleted conditions during ripening. J Agric Food Chem. 2008:56(14):5905-15.

63. Pfaffl MW. Chapter3. Quantification strategies in real-time PCR. In: Bustin SA, editor. A-Z of quantitative PCR. La Jolla, CA, USA: International University Line; 2004. p. 87-112.

64. Thimm O, Blasing O, Gibon Y, Nagel A, Meyer S, Kruger P, et al. MAPMAN: a user-driven tool to display genomics data sets onto diagrams of metabolic pathways and other biological processes. Plant J. 2004;37(6):914-39.

\section{Submit your next manuscript to BioMed Central and take full advantage of:}

- Convenient online submission

- Thorough peer review

- No space constraints or color figure charges

- Immediate publication on acceptance

- Inclusion in PubMed, CAS, Scopus and Google Scholar

- Research which is freely available for redistribution 